\title{
Hubungan Dukungan Keluarga dengan Keaktifan Lansia Mengikuti Kegiatan Posyandu di Desa Lumban Sinaga Wilayah Kerja Puskesmas Lumban Sinaga Kecamatan Pangaribuan Kabupaten Tapanuli Utara Tahun 2017
}

\author{
Elderly Follows Integrated Service Post Activities in Lumban Sinaga Village, \\ Community Health Centers Area Lumban Sinaga Kecamatan Pangaribuan \\ District Tarauli Utara
}

\author{
Daniel Ginting ${ }^{1}$, Netti Etalia br Brahmana*2 \\ ${ }^{1,2}$ Program Studi Kesehatan Masyarakat, Universitas Sari Mutiara Indonesia, Jln Kapten Muslim No. 77 Medan, 20123, \\ Indonesia \\ *Korespondensi Penulis: birink_netti@yahoo.com
}

\begin{abstract}
Abstrak
Lansia memiliki permasalahan khusus yang mencakup berlangsungnya proses menua yang berakibat timbulnya masalah fisik, mental maupun sosial, berkurangnya integrasi sosial lanjut usia, rendahnya produktivitas kerja lansia, banyaknya lansia yang miskin, terlantar dan cacat, adanya dampak negatif dari proses pembangunan yang dapat mengganggu kesehatan fisik lansia. Salah satu upaya untuk mengatasi masalah kesehatan tersebut adalah melalui posyandu lansia. Presentase tingkat keaktifan lansia mengikuti kegiatan posyandu di Desa Lumban Sinaga wilayah kerja Puskesmas Lumban Sinaga masih tergolong rendah, dimana kehadiran lansia masih jauh dari target. Penelitian ini bertujuan untuk mengetahui hubungan dukungan keluarga dengan keaktifan mengikuti kegiatan posyandu di Desa Lumban Sinaga Wilayah Kerja Puskesmas Lumban Sinaga Kecamatan Pangaribuan Kabupaten Tapanuli Utara Tahun 2017. Penelitian ini adalah analitik dengan pendekatan cross sectional. Penelitian dilakukan dari bulan Februari-Agustus 2017. Populasi dalam penelitian ini adalah seluruh lansia yang terdaftar di Posyandu Desa Lumban Sinaga yaitu sebanyak 39 orang dan seluruhnya dijadikan sampel dengan menggunakan teknik total populasi. Uji statistik yang digunakan adalah uji chi square. Hasil penelitian didapatkan dukungan keluarga mayoritas kurang yaitu sebanyak 48,7\% dan keaktifan lansia mengikuti kegiatan posyandu adalah mayoritas tidak aktif yaitu sebanyak $66,7 \%$. Ada hubungan yang signifikan antara dukungan keluarga dengan keaktifan lansia mengikuti kegiatan posyandu lansia $\mathrm{p}$ value $=0,007$. Untuk itu disarankan bagi keluarga untuk dapat meningkatkan dukungannya bagi lansia agar lansia semakin aktif mengikuti kegiatan posyandu, bagi puskesmas juga diharapkan untuk memotivasi dan mengarahkan keluarga lansia untuk mendukung lansia mengikuti kegiatan posyandu serta meningkatkan kualitas pelayanan kesehatan di posyandu lansia.
\end{abstract}

Kata Kunci: Dukungan Keluarga, Keaktifan Lansia, Mengikuti Kegiatan Posyandu 


\begin{abstract}
Elderly people have special problems that include the aging process which results in physical, mental and social problems, reduced social integration in the elderly, low work productivity of the elderly, many poor, displaced and disabled elderly people, negative impacts of the development process that can disrupt physical health the elderly. One effort to overcome these health problems is through the posyandu for the elderly. The percentage of the level of activity of the elderly participating in the posyandu activities in Lumban Sinaga Village, the working area of Lumban Sinaga Health Center is still relatively low, where the presence of the elderly is still far from the target. This study aims to determine the relationship of family support with the activity of participating in the posyandu activities in the Lumban Sinaga Village in the Lumban Sinaga Community Health Center Working Area in Pangaribuan District, North Tapanuli Regency in 2017. This study was an analytic with cross sectional approach. The study was conducted from February to August 2017. The population in this study were all elderly people registered at the Posyandu in Lumban Sinaga Village as many as 39 people and all were sampled using the total population technique. The statistical test used is the chi square test. The results of the study found that the majority of the family support was less, namely as much as $48.7 \%$ and the activity of the elderly following the posyandu activities was the majority of inactivity, which was $66.7 \%$. There is a significant relationship between family support and the activity of the elderly in the elderly posyandu activities $p$ value $=0.007$. It is recommended for families to increase their support for the elderly so that the elderly are more actively participating in the posyandu activities. Puskesmas are also expected to motivate and direct the elderly family to support the elderly to participate in the posyandu activities and improve the quality of health services at the posyandu for the elderly.
\end{abstract}

Keywords: Family Support, Active Activity of Elderly, Participating in Posyandu Activities

\title{
PENDAHULUAN
}

Seiring dengan keberhasilan pemerintah dalam pembangunan nasional, telah mewujudkan hasil yang positif di berbagai bidang, yaitu adanya kemajuan ekonomi, perbaikan lingkungan hidup, kemajuan ilmu pengetahuan dan teknologi, terutama di bidang medis sehingga dapat meningkatkan kualitas kesehatan penduduk. Akibatnya jumlah penduduk lansia meningkat dan bertambah cenderung lebih cepat (Siti Bandiyah, 2014).

Menurut WHO kelompok lansia dibagi menjadi beberapa kelompok meliputi usia pertengahan yaitu usia 45-59 tahun, lansia yaitu usia 60-74 tahun, lansia tua yaitu usia 75-90 tahun, dan lansia sangat tua diatas 90 tahun. Di seluruh dunia, jumlah lansia diperkirakan lebih dari 629 juta jiwa. Tahun 2025 lansia akan mencapai 1,2 milyar. Di Indonesia presentasi lansia lima tahun terakhir mengalami kenaikan, dimana pada tahun 2012 sebanyak 7,9\%, tahun 2013 sebanyak 8,0\%, tahun 2014 sebanyak 8,2\%, tahun 2015 sebanyak 
8,5\%,tahun 2016 sebanyak 8,7\%. Jumlah penduduk lansia di Provinsi Sumatera Utara pada tahun 2015 mencapai 945.357 jiwa (6,8\%), dan jumlah lansia di posyandu Desa Lumban Sinaga wilayah kerja Puskesmas Lumban Sinaga sebanyak 39 orang.

Dampak dari peningkatan jumlah lansia terdapat permasalahan khusus yang mencakup berlangsungnya proses menua yang berakibat timbulnya masalah fisik, mental maupun sosial, berkurangnya integrasi sosial lanjut usia, rendahnya produktivitas kerja lansia, banyaknya lansia yang miskin, terlantar dan cacat, berubahnya nilai sosial masyarakat yang mengarah pada tatanan masyarakat individualistik, dan adanya dampak negatif dari proses pembangunan yang dapat mengganggu kesehatan fisik lansia (Sunaryo, 2016).

Mengatasi masalah kesehatan lansia tersebut pemerintah telah mencanangkan pelayanan pada lansia salah satunya adalah posyandu lansia. Posyandu lansia adalah pos pelayanan terpadu untuk masyarakat usia lanjut di suatu wilayah tertentu yang sudah disepakati dan digerakkan oleh masyarakat dimana mereka bisa mendapatkan pelayanan kesehatan. Tujuan dari pembentukan posyandu lansia yaitu meningkatkan derajat kesehatan dan mutu pelayanan kesehatan usia lanjut di masyarakat (Ismawati, 2010).

Kegiatan posyandu lansia yang dilakukan setiap satu bulan sekali yang meliputi pemeriksaan aktifitas kegiatan sehari-hari, pemeriksaan status mental, pemeriksaan status gizi melalui penimbangan berat badan dan pengukuran tinggi badan dan dicatat pada grafik Indeks Massa Tubuh (IMT), pengukuran tekanan darah, denyut nadi, pemeriksaan hemoglobin, pemeriksaan adanya gula dalam air seni sebagai deteksi awal adanya penyakit gula (diabetes mellitus), pemeriksaan adanya zat putih telur (protein) dalam air seni sebagai deteksi awal adanya penyakit ginjal, penyuluhan dan konseling kesehatan, Pemberian Makanan Tambahan (PMT), kegiatan lain yang dapat dilakukan sesuai kebutuhan dan kondisi setempat, kegiatan olah raga antara lain senam lansia, gerak jalan santai, dan lain sebagainya.

Keaktifan lansia ke posyandu lansia merupakan suatu perilaku atau tindakan nyata yang bisa dilihat dari keteraturan dan keterlibatan dalam mengikuti kegiatan posyandu. Faktorfaktor penting dalam keaktifan mengikuti kegiatan posyandu lansia salah satunya dukungan keluarga. Dukungan keluarga merupakan sikap, tindakan dan penerimaan keluarga untuk mendukung dan memberikan bantuan dalam bentuk dukungan emosional, informasi, instrumental dan penilaian. 
Dukungan keluarga sangat berperan dalam mendorong minat atau kesediaan lansia untuk mengikuti kegiatan posyandu lansia, dimana faktor usia mempengaruhi lansia karena semua fungsi ingatan, penglihatan, pendengaran, daya konsentrasi dan kemampuan fisik secara umum mulai menurun sehingga memerlukan orang lain untuk memenuhi keperluannya dalam mempertahankan keaktifan mengikuti posyandu lansia (Handoko, 2008).

Hal ini sejalan dengan penelitian Kresnawati (2011) terdapat hubungan yang signifikan antara dukungan keluarga dengan keaktifan lansia mengikuti kegiatan posyandu di Desa Gonilan Kecamatan Kartasura dengan p value = 0,001.

Hasil survei pendahuluan yang dilakukan di Posyandu Lansia Desa Lumban Sinaga dengan jumlah lansia yang terdaftar sebanyak 39 orang. Pelaksanaan posyandu dilakukan rutin setiap bulan. Jenis kegiatan yang dilaksanakan di posyandu lansia Desa Lumban Sinaga yaitu mulai dari penimbangan berat badan dan pengukuran tinggi badan, pengukuran tekanan darah, pemeriksaan gula darah, kolesterol dan asam urat, penyuluhan kesehatan, pemberian makanan tambahan serta kegiatan senam lansia.

Lansia yang terdapat di Posyandu Lumban Sinaga sebagian besar memiliki masalah kesehatan dimana, terdapat 10 lansia yang mengalami masalah reumatik, 7 lansia dengan masalah asam urat, 7 lansia dengan masalah osteoporosis, 5 lansia dengan masalah hipertensi, 1 lansia dengan masalah diabetes mellitus, penurunan fungsi penglihatan, pendengaran, daya ingat dan 9 lansia lainnya masih memiliki kondisi fisik yang baik. Dari data tersebut diketahui bahwa tingkat ketergantungan lansia masih tinggi, dimana mereka membutuhkan bantuan dan dukungan dari keluarga untuk dapat mengikuti kegiatan posyandu.

Berdasarkan hasil data presentase tingkat kehadiran lansia mengikuti kegiatan posyandu lansia selama tiga bulan terakhir masih jauh dari yang diharapkan. Dimana dari 39 lansia yang terdaftar di Posyandu Lumban Sinaga, yang mengikuti kegiatan posyandu pada bulan Desember 2016 sebanyak 24 orang (61,53\%), pada bulan Januari 2017 sebanyak 20 orang $(51,28 \%)$ dan pada bulan Februari 2017 sebanyak 18 orang (46,15\%).

Setelah melakukan wawancara terhadap 6 lansia yang ditemukan di Posyandu Lansia Desa Lumban Sinaga, mereka mengatakan alasan tidak mengikuti posyandu dikarenakan kondisi fisik yang tidak mampu berjalan kaki menuju posyandu. Hal tersebut dikarenakan jarak rumah dengan lokasi posyandu yang jauh dan sulit dijangkau, sarana dan prasarana yang kurang mendukung, keterbatasan kemampuan keluarga sehingga lebih mementingkan bekerja untuk mencari nafkah. 
Dukungan keluarga kepada lansia untuk mengikuti kegiatan posyandu lansia masih kurang, dimana 4 lansia mengatakan keluarga tidak pernah mengingatkan jadwal posyandu apabila lansia lupa, keluarga tidak pernah mengantarkan lansia ke posyandu, keluarga tidak pernah memberikan semangat untuk mengikuti kegiatan posyandu lansia, keluarga tidak pernah memberi nasehat agar rajin mengikuti kegiatan posyandu lansia dan 2 lansia mengatakan keluarga selalu mengingatkan jadwal posyandu, keluarga selalu mengantar lansia ke posyandu, keluarga menemani lansia dalam kegiatan di posyandu.

Berdasarkan uraian diatas maka perlu dilakukan penelitian tentang hubungan dukungan keluarga dengan keaktifan lansia dalam mengikuti kegiatan posyandu di Desa Lumban Sinaga wilayah kerja Puskesmas Lumban Sinaga Kecamatan Pangaribuan Kabupaten Tapanuli Utara tahun 2017.

\section{METODE PENELITIAN}

Jenis penelitian ini adalah analitik dengan pendekatan cross sectional, dengan tujuan untuk mengetahui hubungan dukungan keluarga dengan keaktifan lansia mengikuti kegiatan posyandu lansia di Desa Lumban Sinaga wilayah kerja Puskesmas Lumban Sinaga Kecamatan Pangaribuan Kabupaten Tapanuli Utara Tahun 2017.

Populasi dalam penelitian ini adalah seluruh lansia yang berusia 60 tahun atau lebih yang terdaftar di Posyandu Desa Lumban sinaga wilayah kerja Puskesmas Lumban Sinaga Kecamatan Pangaribuan yaitu sejumlah 39 orang. Sampel dalam penelitian ini adalah seluruh lansia yang berusia 60 tahun atau lebih yang terdaftar di Posyandu Lansia Desa Lumban Sinaga wilayah kerja Puskesmas Lumban Sinaga sebanyak 39 orang (total populasi).

Data yang dikumpulkan dalam penelitian ini berupa data primer dan data sekunder. Data primer dikumpulkan langsung dengan membagikan kuesioner kepada lansia dengan terlebih dahulu menjelaskan kepada keluarga tentang cara pengisian. Data sekunder adalah data yang diperoleh dari Puskesmas Lumban Sinaga.

Analisis data menggunakan analisis univariat dan analisis bivariat. Analisa univariat untuk mengetahui distribusi frekuensi masing-masing variabel yang telah ditentukan dalam penelitian yaitu umur, jenis kelamin, pendidikan, pekerjaan, dukungan keluarga dan keaktifan lansia. Sedangkan analisa bivariate untuk mengetahui hubungan antara dukungan keluarga dengan keaktifan lansia dalam mengikuti kegiatan posyandu lansia di Desa Lumban Sinaga wilayah kerja Puskesmas Lumban Sinaga Kecamatan Pangaribuan Kabupaten Tapanuli Utara 
tahun 2017, uji statistik yang digunakan uji Chi-Square dengan signifikan 5\% (0,05).

\section{HASIL DAN PEMBAHASAN}

Tabel 1. Distribusi Frekuensi Karakteristik Responden di Posyandu Desa Lumban Sinaga Wilayah Kerja Puskesmas Lumban Sinaga Kecamatan Pangaribuan Kabupaten Tapanuli UtaraTahun 2017

\begin{tabular}{|c|c|c|}
\hline Karakteristik & Jumlah & $(\%)$ \\
\hline \multicolumn{3}{|l|}{ Umur } \\
\hline $60-69$ & 30 & 76,9 \\
\hline $70-80$ & 9 & 23,1 \\
\hline Total & 39 & 100 \\
\hline \multicolumn{3}{|l|}{ Jenis Kelamin } \\
\hline Laki-laki & 2 & 5,1 \\
\hline Perempuan & 37 & 94,9 \\
\hline Total & 39 & 100 \\
\hline \multicolumn{3}{|l|}{ Pendidikan } \\
\hline SD & 10 & 25,6 \\
\hline SMP & 11 & 28,2 \\
\hline SMA & 6 & 15,4 \\
\hline Perguruan Tinggi & 6 & 15,4 \\
\hline Tidak Sekolah & 6 & 15,4 \\
\hline Total & 39 & 100 \\
\hline \multicolumn{3}{|l|}{ Pekerjaan } \\
\hline Petani & 19 & 48,7 \\
\hline Wiraswasta & 4 & 10,3 \\
\hline $\begin{array}{l}\text { Tidak Bekerja di } \\
\text { rumah/Pensiun }\end{array}$ & 16 & 41,0 \\
\hline Total & 39 & 100 \\
\hline
\end{tabular}

Berdasarkan tabel 4.1 di atas dapat dilihat bahwa umur mayoritas 65-69 tahun yaitu $76,9 \%$, jenis kelamin mayoritas perempuan yaitu 94,9\%, pendidikan mayoritas SMP yaitu $28,2 \%$, pekerjaan mayoritas petani yaitu $48,7 \%$. 
Tabel 2. Distribusi Frekuensi Dukungan Keluarga, Keaktifan Lansia, di Posyandu Desa Lumban Sinaga Wilayah Kerja Puskesmas Lumban Sinaga Kecamatan Pangaribuan Kabupaten Tapanuli UtaraTahun 2017

\begin{tabular}{lcc}
\hline Dukungan Keluarga & Jumlah & $\mathbf{( \% )}$ \\
\hline Baik & 7 & 17,9 \\
Cukup & 13 & 33,3 \\
Kurang & 19 & 48,7 \\
\hline Total & $\mathbf{3 9}$ & $\mathbf{1 0 0}$ \\
\hline Keaktifan Lansia & Jumlah & $\mathbf{( \% )}$ \\
\hline Aktif & 13 & 33,3 \\
Tidak Aktif & 26 & 66,7 \\
\hline Total & $\mathbf{3 9}$ & $\mathbf{1 0 0}$ \\
\hline
\end{tabular}

Berdasarkan tabel 2 di atas dapat dilihat dukungan keluarga pada lansia di Posyandu Desa Lumban Sinaga Wilayah Kerja Puskesmas Lumban Sinaga Kecamatan Pangaribuan Kabupaten Tapanuli Utara tahun 2017 mayoritas kurang yaitu 48,7\%. Keaktifan lansia mengikuti kegiatan posyandu lansia di Desa Lumban Sinaga Wilayah Kerja Puskesmas Lumban Sinaga Kecamatan Pangaribuan Kabupaten Tapanuli Utara tahun 2017 mayoritas tidak aktif yaitu $66,7 \%$.

Tabel 3. Tabulasi Silang Hubungan Dukungan Keluarga dengan Keaktifan Lansia di Posyandu Desa Lumban Sinaga Wilayah Kerja Puskesmas Lumban Sinaga Kecamatan Pangaribuan Kabupaten Tapanuli Utara Tahun 2017

\begin{tabular}{|c|c|c|c|c|c|c|c|}
\hline \multirow{3}{*}{$\begin{array}{c}\text { Dukungan } \\
\text { Keluarga }\end{array}$} & \multicolumn{4}{|c|}{ Keaktifan Lansia } & \multirow{2}{*}{\multicolumn{2}{|c|}{ Total }} & \multirow{3}{*}{ p-Value } \\
\hline & \multicolumn{2}{|c|}{ Aktif } & \multicolumn{2}{|c|}{ Tidak Aktif } & & & \\
\hline & $\mathbf{F}$ & $\%$ & $\mathbf{F}$ & $\%$ & $\mathbf{F}$ & $\%$ & \\
\hline Baik & 5 & 12,8 & 2 & 5,1 & 7 & 17,9 & \\
\hline Cukup & 6 & 15,4 & 7 & 17,9 & 13 & 33,3 & 0,007 \\
\hline Kurang & 2 & 5,1 & 17 & 43,6 & 19 & 48,7 & \\
\hline Total & 13 & 33,3 & 26 & 66,7 & 39 & 100 & \\
\hline
\end{tabular}

Berdasarkan tabel 3 di atas dapat diketahui dari 17,9\% dukungan keluarga yang baik, 12,8\% lansia aktif mengikuti kegiatan posyandu dan 5,1\% lansia tidak aktif mengikuti kegiatan posyandu, dari 33,3\% dukungan keluarga cukup, 15,4\% lansia aktif mengikuti kegiatan posyandu dan $17,9 \%$ tidak aktif mengikuti kegiatan posyandu dan dari 48,7\% dukungan keluarga kurang, 5,1\% lansia aktif mengikuti kegiatan posyandu dan 43,6\% lansia tidak aktif mengikuti kegiatan posyandu. 
Hasil uji statistik diperoleh $\mathrm{p}$ value $=0,007$ atau $\mathrm{p}=<0,05$ artinya bahwa ada hubungan yang bermakna antara dukungan keluarga dengan keaktifan lansia mengikuti kegiatan posyandu lansia di Desa Lumban Sinaga Wilayah Kerja Puskesmas Lumban Sinaga Kecamatan Pangaribuan Kabupaten Tapanuli Utara Tahun 2017.

\section{Pembahasan}

1. Dukungan Keluarga

Dari hasil penelitian menunjukkan bahwa dukungan keluarga di Posyandu Lansia Desa Lumban Sinaga Wilayah Kerja Puskesmas Lumban Sinaga Kecamatan Pangaribuan Kabupaten Tapanuli Utara tahun 2017 mayoritas kurang yaitu 48,7\%. Hal ini diketahui dari jawaban responden dalam kuesioner dimana banyak lansia yang mengatakan bahwa keluarga tidak menyediakan transportasi kepada lansia, keluarga tidak mengantar lansia ke posyandu, keluarga tidak memberikan nasehat agar lansia selalu mengikuti kegiatan posyandu, keluarga tidak mengingatkan jadwal kegiatan posyandu, keluarga tidak memberikan informasi tentang manfaat mengikuti kegiatan posyandu, keluarga tidak menanyakan masalah yang dihadapi lansia selama mengikuti kegiatan posyandu dan keluarga juga tidak memberikan semangat kepada lansia untuk mengikuti posyandu.

Masyarakat Desa Lumban Sinaga adalah mayoritas bekerja sebagai petani, dimana keluarga harus bekerja setiap harinya dari pagi hingga sore, ada sebagian masyarakat bekerja sebagai buruh dimana mereka juga harus bekerja dari pagi hingga sore bahkan kadang mereka lembur untuk mencukupi kebutuhan keluarga. Sebagian besar mereka tidak ada waktu untuk mengantar lansia ke posyandu, keluarga lebih mementingkan pekerjaannya dari pada memberikan dukungan dalam bentuk mengingatkan jadwal posyandu kepada lansia, memberikan semangat kepada lansia, menanyakan masalah selama mengikuti kegiatan posyandu dan memberikan informasi tentang manfaat posyandu lansia. Petugas kesehatan juga tidak pernah memberikan informasi kepada keluarga tentang manfaat dukungan keluarga terhadap lansia dalam mengikuti kegiatan posyandu.

Dukungan keluarga merupakan sikap, tindakan dan penerimaan keluarga untuk mendukung dan memberikan bantuan dalam bentuk dukungan emosional, informasional, instrumental dan penilaian. Dukungan keluarga dapat memberikan pengaruh yang positif terhadap kesehatan anggota keluarganya. Bentuk dukungan ini dapat diberikan melalui dua 
cara yaitu secara langsung dan secara tidak langsung. Secara langsung dukungan ini akan memberikan dorongan kepada anggotanya untuk berperilaku sehat, sedangkan secara tidak langsung dukungan yang diterima dari orang lain akan mengurangi ketegangan atau depresi sehingga tidak menimbulkan gangguan (Kaplan, 2012).

Dukungan keluarga sangat berperan dalam mendorong minat atau kesediaan lansia untuk mengikuti kegiatan posyandu. Keluarga bisa menjadi motivator kuat bagi lansia apabila selalu menyediakan diri untuk mendampingi atau mengantar lansia ke posyandu, mengingatkan lansia jika lupa jadwal posyandu lansia dan berusaha membantu segala permasalahan bersama lansia (Erfandi, 2008) dan Menurut Ekasari (2008) ada beberapa hal yang dapat dilakukan oleh anggota keluarga dalam melaksanakan perannya terhadap lansia yaitu melaksanakan pembicaraan terarah, memberi dorongan untuk tetap mengikuti kegiatan di masyarakat, memeriksakan kesehatannya secara teratur, membantu dalam hal transportasi, membantu dalam hal keuangan, memberikan kasih sayang, menyediakan waktu dan perhatian.

Hasil penelitian ini sejalan dengan penelitian sebelumnya yang dilakukan oleh Iwan Priyatno dari STIKES Ngudi Waluyo tahun 2015 di Desa Leyangan. Menunjukkan bahwa dukungan keluarga mayoritas adalah kurang baik yaitu sebanyak 55,8\%, kemudian dukungan keluarga yang baik sebanyak 44,2\%. Artinya keluarga kurang memberikan dukungan dan kurang memperhatikan kebutuhan lansia dalam mengikuti kegiatan posyandu lansia. Kemudian hasil penelitian Handayani (2012) menunjukkan bahwa sebagian besar lansia mempunyai dukungan keluarga yang rendah disebabkan karena lansia tidak diingatkan jadwal posyandu oleh keluarganya, karena keluarga sibuk bekerja dan keluarga tidak memberikan semangat pada lansia dalam menghadiri posyandu lansia.

Menurut peneliti bahwa pemberian dukungan keluarga terhadap lansia masih belum maksimal disebabkan karena kesibukan keluarga dalam bekerja dan kepedulian yang masih kurang akan pentingnya dukungan keluarga bagi lansia, mereka bekerja setiap harinya dari pagi sampai sore bahkan ada sebagian buruh yang harus lembur sehingga keluarga lebih mementingkan pekerjaan mereka. Agar dapat memberikan dukungan yang baik, keluarga harus mempunyai keyakinan serta kesadaran bahwa lansia membutuhkan dukungan yang baik dari keluarga, petugas kesehatan melibatkan keluarga untuk mendukung lansia mengikuti posyandu. 


\section{Keaktifan Lansia Mengikuti Kegiatan Posyandu Lansia}

Hasil penelitian menunjukkan bahwa keaktifan lansia mengikuti kegiatan posyandu di Desa Lumban Sinaga Wilayah Kerja Puskesmas Lumban Sinaga Kecamatan Pangaribuan Kabupaten Tapanuli Utara Tahun 2017 mayoritas dalam kategori tidak aktif sebanyak 66,7\% diantaranya 3 lansia yang mengikuti kegiatan posyandu hanya 66,6\% dalam satu tahun, ada 4 lansia yang mengikuti posyandu 58,33\% dalam satu tahun, 7 lansia yang mengikuti posyandu sebanyak 50\%, 4 lansia yang mengikuti posyandu 41,66\%, 4 lansia mengikuti posyandu 33,33\%, 3 lansia yang mengikuti posyandu 25\%, dan bahkan ada 1 orang lansia yang mengikuti posyandu hanya 16,66\% dalam satu tahun.

Dari 33,3\% lansia yang aktif diantaranya 2 lansia yang mengikuti posyandu $75 \%$ dalam satu tahun, 2 lansia mengikuti posyandu 83,3\% dalam satu tahun, 2 lansia mengikuti posyandu $91,6 \%$ dalam satu tahun, bahkan ada 7 lansia yang mengikuti kegiatan posyandu $100 \%$ dalam satu tahun. Hal ini diperoleh berdasarkan daftar hadir lansia setiap bulannya, bahwa kategori keaktifan lansia yang paling dominan yaitu mengikuti kegiatan posyandu kurang dari 9 kali dalam satu tahun. Dimana lansia yang dikatakan aktif apabila mengikui kegiatan posyandu minimal $75 \%$ dalam satu tahun.

Berdasarkan wawancara kepada lansia yang tidak aktif mengikuti kegiatan posyandu diperoleh bahwa alasan mereka tidak aktif mengikuti kegiatan posyandu karena sering lupa jadwal kegiatan posyandu, diamana hal tersebut disebabkan faktor usia lansia yang sudah mencapai 60 sampai 80 tahun. Tidak ada yang mengantar lansia ke posyandu, mereka tidak sanggup berjalan kaki dari rumah ke tempat posyandu dikarenakan banyak lansia mengalami masalah kesehatan seperti asam urat, reumatik, osteoporosis, diabetes mellitus, hipertensi dan juga mudah mengalami kelelahan. Lansia juga sebagian besar bekerja sebagai petani sebagian lansia kadang tidak mengikuti kegiatan posyandu karena bekerja di ladang.

Hal tersebut dikarenakan sebagian jarak rumah dengan lokasi posyandu yang jauh atau sulit dijangkau dengan kondisi fisik yang tidak mampu berjalan kaki menuju posyandu. Mereka sering tidak mengikuti posyandu karena lupa dengan jadwal yang telah ditetapkan. Jarak posyandu yang dekat akan membuat lansia mudah menjangkau posyandu tanpa harus mengalami kelelahan fisik karena penurunan daya tahan atau kekuatan fisik tubuh. 
Sejalan dengan teori Sunaryo (2016) kendala pelaksanaan posyandu lansia yaitu pengetahuan yang rendah tentang manfaat posyandu lansia, jarak rumah yang jauh dari lokasi posyandu, kurangnya dukungan keluarga, dan sikap yang kurang baik terhadap petugas kesehatan. Kemudahan dalam menjangkau lokasi posyandu ini berhubungan dengan faktor keamanan atau keselamatan bagi lansia, jika lansia merasa aman atau merasa mudah untuk menjangkau lokasi posyandu tanpa harus menimbulkan kelelahan atau masalah yang serius, maka hal ini dapat mendorong minat atau motivasi lansia untuk mengikuti kegiatan posyandu.

Keamanan ini merupakan faktor eksternal dari terbentuknya motivasi untuk menghadiri kegiatan posyandu lansia. Menurut Erfandi 2008 bahwa faktor-faktor yang mempengaruhi lansia aktif mengikti kegiatan posyandu salah satunya adalah kondisi fisik lansia. Hal ini sejalan dengan hasil penelitian Abu Hanifah (2015) tentang keaktifan lansia mengikuti kegiatan posyandu, dimana dari hasil diketahui lansia mayoritas tidak aktif sebanyak 34 orang $(50,7 \%)$ dan lansia yang aktif sebanyak 33 orang $(49,3 \%)$.

Menurut peneliti ketidak aktifan lansia mengikuti kegiatan posyandu disebabkan karena beberapa hal. Dari faktor lansia bisa saja karena kondisi fisik yang tidak memungkinkan untuk mrngikuti kegiatan posyandu, kurangnya motivasi dari diri sendiri misalnya lansia merasa posyandu tidak begitu bermanfaat untuk dirinya karena tidak semua pemeriksaan kesehatan dilakukan setiap bulannya, lansia merasa kurang tertarik dengan kegiatan posyandu. Dari faktor lain yang paling penting adalah kurangnya dukungan dari keluarga baik berupa instrumental, informasional, emosional dan juga penilaian. Maka agar lansia aktif mengikuti kegiatan posyandu, yang terutama lansia harus mempunyai dukungan dari keluarga yang baik, serta kondisi fisik lansia yang sehat, dan juga harus ada motivasi dari diri sendiri.

3. Hubungan Dukungan Keluarga dengan Keaktifan Lansia Mengikuti Kegiatan Posyandu

Pengujian Hipotesis penelitian tentang adanya hubungan dukungan keluarga dengan keaktifan mengikuti kegiatan posyandu lansia di Desa Lumban Sinaga dengan hasil uji statistik menunjukkan bahwa $\mathrm{p}$ value $=0,007$ maka diperoleh kesimpulan analisis adalah ada hubungan signifikan dukungan kelurga dengan keaktifan mengikuti kegiatan posyandu lansia di Desa Lumban Singa Wilayah Kerja Puskesmas Lumban Sinaga Kecamatan Pangaribuan Kabupaten Tapanuli Utara Tahun 2017.

Hasil analisis hubungan dukungan keluarga dengan keaktifan lansia mengikuti 
kegiatan posyandu di Desa Lumban Singa Wilayah Kerja Puskesmas Lumban Sinaga Kecamatan Pangaribuan Kabupaten Tapanuli Utara Tahun 2017 diperoleh hasil, responden yang mendapat dukungan keluarga kategori kurang sebanyak 48,7\% dimana sebagian besar mereka tidak aktif mengikuti posyandu, dan responden yang memiliki dukungan keluarga baik sebagian besar aktif mengikuti kegiatan posyandu. Hal tersebut menunjukkan bahwa keluarga yang tidak mendukung dalam mengikuti kegiatan posyandu menyebabkan lansia tidak aktif dalam mengikuti kegiatan posyandu.

Responden yang aktif mengikuti posyandu lansia adalah mereka yang keteraturan dan keterlibatannya aktif dalam kegiatan yang diadakan di posyandu lansia mencangkup upaya-upaya perbaikan dan peningkatan kesehatan masyarakat. Lansia yang aktif mengikuti kegiatan posyandu lansia minimal mereka mengikuti kegiatan 9 kali ( $\geq 75 \%)$ dalam satu tahun.

Sebagian besar lansia yang mendapatkan dukungan keluarga yang kurang, baik yang bersifat instrumental, informasional, penilaian dan emosional seperti keluarga tidak mengantarkan lansia keposyandu, keluarga tidak memberikan informasi tentang manfaat posyandu lansia, keluarga tidak memberikan semangat agar lansia rajin mengikuti posyandu, sehingga lansia kurang termotivasi mengikuti posyandu lansia.

Penelitian ini menunjukkan bahwa terdapat dua 2 lansia yang memiliki dukungan kurang namun aktif mengikuti kegiatan posyandu, terdapat 2 lansia yang dukungan keluarga baik namun tidak aktif mengikuti kegiatan posyandu. Dari hasil observasi pada lansia yang dukungan keluarganya kurang namun aktif mengikuti kegiatan posyandu menunjjukan lansia tersebut telah mengetahui manfaat dari posyandu lansia untuk kesehatan sehingga mereka semangat dan termotivasi untuk aktif mengikuti kegiatan posyandu, serta mereka mengatakan bahwa di posyandu mereka bisa berinteraksi dengan teman lainnya sehingga mereka semangat mengikuti kegiatan posyandu.

Lansia yang mendapatkan dukungan keluarga baik namun tidak aktif mengikuti kegiatan posyandu, dikarenakan lansia sering mengalami gangguan kesehatan seperti sakit pada persendian kaki hingga kadang sulit untuk berdiri, kemudian kondisi tubuh yang tiba-tiba lemas, sehingga meskipun dukungan keluarganya baik, namun karena kondisi kesehatan lansia tidak memungkinkan maka lansia sering tidak mengikuti kegiatan posyandu. 
Menurut Erfandi (2008) faktor yang mempengaruhi keaktifan lansia mengikuti kegiatan posyandu adalah pengetahuan lansia tentang manfaat posyandu, dukungan keluarga, motivasi lansia, dan kondisi fisik lansia. Dukungan keluarga sangat berperan dalam mendorong minat atau kesediaan lansia untuk mengikuti kegiatan posyandu lansia. Dimana faktor usia mempengaruhi lansia karena semua fungsi ingatan, penglihatan, pendengaran, daya konsentrasi dan kemampuan fisik secara umum mulai menurun sehingga memerlukan orang lain untuk memenuhi keperluannya dalam mempertahankan keaktifan mengikuti posyandu lansia (Handoko, 2008).

Hasil uji statistik didapatkan nilai p Value sebesar 0,007 maka dapat disimpulkan ada hubungan dukungan keluarga dengan keaktifan lansia mengikuti kegiatan posyandu di.Lumban Sinaga Wilayah Kerja Puskesmas Lumban Sinaga Kecamatan Pangaribuan Kabupaten Tapanuli Utara Tahun 2017. Hasil penelitian ini memperkuat penelitian Kresnawati (2011) bahwa ada hubungan yang signifikan antara dukungan keluarga dengan keaktifan lansia dalam mengikuti kegiatan posyandu di Desa Gonilon Kecamatan Kartasura dengan $\mathrm{p}$ value $=0,001$.

Menurut asumsi peneliti semakin baik dukungan keluarga maka tingkat keaktifan lansia mengikuti kegiatan posyandu akan semakin baik, sebaliknya apabila semakin rendah dukungan keluarga maka tingkat keaktifan lansia mengikuti kegiatan posyandu juga akan semakin rendah. Namun ada sebagian kecil responden yang memiliki dukungan keluarga baik tetapi tidak aktif mengikuti kegiatan posyandu ataupun sebaliknya. Menurut analisa peneliti hal ini terjadi mungkin karena ada faktor lain diluar dukungan keluarga berupa pengetahuan dan kondisi fisik yang tidak memungkinkan sehingga tidak dapat memanfaatkan secara maksimal dukungan dari keluarga sehingga dukungan tersebut tidak berpengaruh terhadap keaktifan lansia mengikuti kegiatan posyandu.

\section{DAFTAR PUSTAKA}

Bandiyah. S, 2014. Lanjut Usia dan Keperawatan Gerontik. Yogyakarta : Nuha Medika.

Depkes RI, 2006. Indikator Indonesia Sehat 2010 dan Pedoman Penetapan Indikator Provinsi Sehat dan Kabupaten/Kota Sehat. Jakarta

Dinas Kesehatan Propinsi Sumatera Utara, 2015. Profil Kesehatan Provinsi Sumatera Utara. Jakarta.

Ekasari, 2008. Mengenal Usia Lanjut dan Perawatannya. Jakarta: Salemba Medika

Erfandi, 2008. Pengelolaan Posyandu Lansia. Diperoleh tanggal 02-05-2017 
Erpandi, 2016. Posyandu Lansia. Jakarta : EGC.

Hanifah. A, 2015. Hubungan Dukungan Keluarga dengan Keaktifan Mengikuti Kegiatan Posyandu Lansia di Pekon Sari Bumi Kecamatan Gading Rejo Kabupaten Pringsewu. Diperoleh tanggal 27-02-2017.

Iwan, 2015. Hubungan Dukungan Keluarga dengan Keaktifan kunjungan Lansia ke Posyandu lansia Di Desa Leyangan Kecamatan Ungaran Timur Kabupaten Semarang. Diperoleh tanggal 27-03-2017.

Kaplan, 2012. Buku Ajar Psikiatri Klinis. Jakarta: EGC

Kemenkes RI, 2014. UU RI Nomor 13 Tahun 1998 Tentang Kesejahteraan Lanjut usia.

Kresnawati, 2011. Hubungan Dukungan Keluarga dengan Keaktifan Mengikuti Kegiatan Posyandu Lansia di Desa Gonilan Kecamatan Kartasura. Diperoleh tanggal 1303-2017

Lilik, 2011. Keperawatan Lanjut Usia. Yogyakarta : 2011.

Mahara, D. 2012. Faktor-faktor yang Mempengaruhi Keaktifan Lansia dalam Mengikuti Kegiatan Posyandu Lansia di Desa Kauman Kecamatan Polanharjo Kabupaten Klaten. Diperoleh tanggal 07-04-2017.

Notoatmodjo. S, 2016. Metodologi Penelitian Kesehatan. Jakarta : Rineka Cipta.

Nugroho, 2009. Keperawatan Gerontik. Jakarta : Penerbit Buku Kedokteran EGC

Purnawati N. 2014. Faktor-faktor yang mempengaruhi kunjungan lansia dalam kegiatan posyandu di Desa Plumbon Kecamatan Mojolaban Sukoharjo Surakarta. Diperoleh tanggal 10-042017

Puspitasari, Dian. 2014. Hubungan Tingkat Pengetahuan dan Dukungan Keluarga dengan Keaktifan Lansia dalam Mengikuti Kegiatan di Posyandu Lansia Desa Gajahan Kecamatan Colomadu. Diperoleh tanggal 20-04-2017.

Setiadi, 2008. Konsep dan Proses Keperawatan Keluarga. Yogyakarta : Graha Ilmu.

Sudjana, 2005. Metoda Statistik. Bandung : Tarsito.

Sulistyo, 2012. Keperawatan Keluarga. Yogyakarta : Graha Ilmu.

Sunaryo dkk, 2016. Asuhan Keperawatan Gerontik. Yogyakarta : Andi. 